Bull. Fac.Agric.,Cairo Univ., 63: 108-115 (2012).

\title{
EFFECT OF APPLICATION OF DIFFERENT LEVELS OF COBLT ON YEILD, NODULE FORMATION, NPK CONTENT AND PHOTOSYNTHETIC PIGMENTS OF ALFALFA (Medicago sativa L.) PLANT IN A CALCAREOUS SOIL
}

(Received: 21.1.2012)

\author{
By \\ N. A. Aziz \\ Horticulture Department, College of Agriculture, Kirkuk University,Iraq
}

\begin{abstract}
Soil samples were collected randomly from Kirkuk Governorate with relatively high content of lime at a depth of $(0-30) \mathrm{cm}$. Pot experiment was performed in a complete randomized design ( CRD ) with four replications during 20May 2011 - 30July2011 using Alfalfa (Vernal variety) as a test plant . Different concentrations of cobalt $(0,10,25,35,50,75,100,150$ and 200$) \mathrm{mg} / \mathrm{kgsoil}$ as cobalt sulfate were added. Plant samples were collected after 60 days of germination. Nitrogen, phosphorous , potassium, photosynthetic pigments and protein content of alfalfa (Medicago sativa L) plants were determined. The results indicate that the applications of different levels of cobalt $(10-50) \mathrm{mg} / \mathrm{kgsoil} \mathrm{led}$ to an increase in biomass accumulation and yield responses to cobalt and always accompanied by increasing nitrogen phosphorous and potassium concentrations in both shoots and roots and protein content of shoot, an increasing in nodule formation and photosynthetic pigments content was also observed . The highest value of all studied parameters were found at a level of $50 \mathrm{mgCo} / \mathrm{kgsoil} \mathrm{with} \mathrm{a}$ significant difference. Gradual decline was observed with increasing the cobalt levels . However the cobalt contents in shoots, root and nodule of alfalfa plant were significantly increased by increasing cobalt level with a correlation coefficient of $R^{2}=0.956, R^{2}=9839$ and $R^{2}=0.9564$, respectively, and the root cobalt content was higher than those obtained for shoots . From the present investigation it can be concluded that the application of $50 \mathrm{mgCo} / \mathrm{kg}$ soil is beneficial for alfalfa plant growth in a soil with a high lime content.
\end{abstract}

Key words: cobalt, Kirkuk, nodulation, calcareous soil.

\section{INTRODUCTION}

Alfalfa(Medicago sativa L.) is a plant with long history of use around the world as a livestock feed. Middle-Eastern cultures have long used alfalfa as fodder for horses claiming increased speed and strength in animals fed on alfalfa hay tend to gain faster, produce more milk, and maintain themselves in better conditions than those fed on forages. The quality of alfalfa protein is excellent with more than $70 \%$ of its total protein being digestible, (Bruce and Riggs 2002).

Alfalfa is a legume that should fix most of its own $\mathrm{N}$ requirement if it is sufficiently nodulated by viable Rhizobium meliloti inoculum grown on ,efficiency of $\mathrm{N}$ fixation depends on adequate plant levels of other nutrients especially $\mathrm{P}, \mathrm{S}$ and Mo and nontoxic levels of $\mathrm{Al}$ and $\mathrm{Mn}$, (Mihler and Tindau 2002) .

Nitrogen is one of the most abounsant mineral elements, which is a component of all enaymes nucleic acids and a number of other metabolites, it is obtained by the plants from soil in the form of nitrate, ammonium or by fixation of the atmospheric nitrogen $\mathrm{N}_{2}$ by leguminous plants (Marschner , 2003).

Cobalt is essential for the growth of symbiotic microorganisms such as Rhizobia, free living $\mathrm{N}_{2^{-}}$ fixing and blue algae ( Halvin et al., 2005) . It is an integral component of the coenzyme coblamine (vitamin B12 and its derivatives), its deficiency has been found to affect nodule development and function at different levels (Dilworth et al .,1979) ,but at higher concentrations as other trace elements is toxic and may severely interfere with physiological and biochemical functions ( ElSheekh et al ., 2003 ) . Bacteria on root nodules of some legumes require cobalt (and other trace elements ) to synthesize $\mathrm{B}_{12}$ and fix nitrogen from air (Hala , 2007) and it has been categorized as a beneficial element for plants (Marschner, 2003 ; Pilon-Smits et al . 2009 ). Also cobalt is required 
for the synthesis of leghemoglobine and is thus an essential nutrient element for legumes (O. Hara , 2001). In addition, legumes and some other plants have a cobalt requirement independent of nitrogen fixation, although the amount required is small compared to that for the nitrogen - fixation process ( Brady and Ray, 2000) .

The aim of this investigation was executed with an objective to study the effect of different levels of Cobalt on yield, nitrogen, phosphorous and potassium contents of plant, nodule formation, photosynthetic pigments and protein content of alfalfa (Medicago sativa L.) in a calcareous soil.

\section{MATERIAL AND METHODS}

Soil samples were collected randomly from Kirkuk Governorate ( $X=0443729$ Y $=3921505$ $\mathrm{Z}=316$ ) with relatively high content of lime. at a depth of $(0-30) \mathrm{cm}$. The experiments were conducted in earthen pots containing $4 \mathrm{~kg}$ of air dried soil. The inner surface of the pots was lined with polyethylene sheet. The experiment was performed in a complete randomized design(CRD) with four replications during 20 May $2011-30$ July 2011. Each pot was fertilized with $400 \mathrm{ml}$ Hoagland nutrient solution free of nitrogen $1.25 \mathrm{mM} \mathrm{CaSO}{ }_{4}, 0.5 \mathrm{mM} \mathrm{MgSO}{ }_{4} .7 \mathrm{H}_{2} \mathrm{O}, 0.25 \mathrm{mM}$ $\mathrm{KH}_{2} \mathrm{PO}_{4}, 11.6 \mu \mathrm{M} \mathrm{H}_{3} \mathrm{BO}_{3}, 4.6 \mu \mathrm{M} \mathrm{MnSO} \mathrm{M}_{4} .7 \mathrm{H}_{2} \mathrm{O}$, $0.25 \mu \mathrm{M} \mathrm{ZnSO}{ }_{4} 7 \mathrm{H}_{2} \mathrm{O}, 0.12 \mu \mathrm{M} \mathrm{Na} \mathrm{NoO}_{2} .2 \mathrm{H}_{2} \mathrm{O}$, $0.08 \mu \mathrm{MCuSO}_{4} .5 \mathrm{H}_{2} \mathrm{O}$ and $10 \mu \mathrm{M} \mathrm{Fe}$ as $\mathrm{Fe}(\mathrm{III})-$ EDTA(Fodor et al. (1998), twelve seeds of alfalfa (Vernal variety) were germinated in each pot , different concentrations of cobalt $(0,10,25,35$ $, 50,75,100,150$ and $200 \mathrm{mgCo} / \mathrm{kgsoil} \mathrm{)} \mathrm{as} \mathrm{cobalt}$ sulfate were added and the water content of the pot was adjusted to $75 \%$ of field capacity throughout the experimental period by weight method.

The plant samples were collected after 60 days of germination using hand cutting the shoots $1 \mathrm{~cm}$ above the soil surface (Saeed, 1989) and prepared for further analysis on fresh and dried samples.

The particle size distribution of the soil was determined according to the international pipette method as described by Black,(1965). Field capacity was calculated according Karim,(2000).

Electrical conductivity at $25^{\circ} \mathrm{C}$ was measured for the saturation extract as described in Hesse (1971). Soil pH , available phosphorous and potassium of the soil were measured as described in Ryan et al,(2001) . Organic matter (OM), cation exchange capacity (CEC) and soluble cation and anions were determined as described in
Black (1965). Total carbonate content was determined by adding $1 \mathrm{NHCl}$ and the excess of $\mathrm{HCl}$ titrated with $1 \mathrm{~N} \mathrm{NaOH}$ using phenolphthalein indicator as described in ( Rowell,1996). Active calcium carbonate estimated titremetrically using Drouineau procedure Soil samples were shaken with $0.2 \mathrm{~N}$ ammonium oxalate solution to precipitate calcium as calcium oxalate and the excess of ammonium oxalate was determined by titration with potassium permanganate as described by ( Kozhekov and Yakovleva 1977 )

Total cobalt in the soil was determined by digestion according to Jackson (1973) , then determined using Atomic Absorption Spectrophotometer(model Varian 2005).

Available cobalt was extracted from the soil using extracting solution prepared by $0.005 \mathrm{M}$ DTPA (Diethylene triamine penta acetic acid ) with $0.01 \mathrm{M}$ calcium chloride, and $0.1 \mathrm{M}$ ( TEA ) Triethanolamine and the $\mathrm{pH}$ adjusted at 7.3 according to Lindsayand Norvell ( 1978) .

The photosynthetic pigments such as chlorophyll and carotenoid were estimated by grounding $200 \mathrm{mg}$ of fresh leaves with $40 \mathrm{ml}$ of $80 \%$ acetone, the homogenate was centrifuged at $3000 \mathrm{rpm}$ for 15 minutes, the supernatant was saved, the pellet was extracted with $5 \mathrm{ml}$ of $80 \%$ acetone each time until it become colorless, all the supernants were pooled and utilized for chlorophyll and carotinoid determination. Absorbance was measured at $645 \mathrm{~nm}, 663 \mathrm{~nm}$ and $480 \mathrm{~nm}$, chlorophyll was determined using Arnon formula and carotenoid was determined using Kirk and Allen formula (Bruins et al.,2000), the results were expressed in $\mathrm{mg} / \mathrm{gm}$ fresh weight .

Statistical analysis was performed using statistical package for social science ( SPSS ) and Duncan's Multiple Range ( DMRT ), the values are mean of four in each group . $p$ values $<0.05$ were considered as significant.

Harvested shoots were weighed and dried at $60^{\circ} \mathrm{C}$ for $24 \mathrm{hrs}$ to determine the dry matter yields, dried plant materials were ground and prepared for further analysis.

Total nitrogen was determined in dry plant using Kjeldhal method as described in Rowell (1996). Total phosphorous and potassium were estimated in digested plants as described in Page (1982). Protein content was determined by multiplying total nitrogen values by 6.25 ( Khalil et al., 2006 ). From the remaining pot contents the roots were sorted out carefully and the nodules were counted . Cobalt concentrations were determined in plants digested with diacid method using Atomic 
Absorption Spectrophotometer ( model Varian 2005 ).

\section{RESULTS AND DISCUSSION}

Some physical and chemical properties of the studied soils are shown in Table ( 1 ). The soil used in this study contained a high level of total $\mathrm{CaCO}_{3}$ and active lime with a pHs of 7.86 .Applications of different levels of cobalt $(10-50)$ $\mathrm{mg} / \mathrm{kgsoil}$ led to an increase in biomass accumulation with a significant effect $(\mathrm{P}<0.05)$ in this calcareous soil. The production of dry matter of roots and shoots was the highest at the application rate of $50 \mathrm{mgCo} / \mathrm{kgsoil}$ and a gradual decline in dry matter production observed with increasing the cobalt levels. The lower value was obtained at $200 \mathrm{mgCo} / \mathrm{kg}$ soil (Fig1). These results are in a good agreement with a large number of reports which indicate increasing of dry matter yield of various plants at lower Cobalt levels ( Jayakumar and Vijayarengan , 2006) and the reduction in dry matter yield of plants at higher concentration of heavy metals (Vijayarengan , 2004). Other investigators found that a numerous plant species and varieties were significantly affected by cobalt applications such Cucumber (Scott and Withman 1976,Parsley ( Laila and , Nada , 2002) and Cowpea (Abdel-Moez and Nadia , 2002) Ground nut (Basu et al., 2006) . Yield responses to cobalt were always accompanied by increasing nitrogen concentration in both shoots and roots and the highest value of nitrogen and protein contents of shoot were recorded at 50mgCo/kgsoil. (Fig. 2) (Table 3). The shoot and root phosphorous content under different cobalt treatment showed that the highest value of $0.286 \%$ , $0.220 \%$ was obtained at the application of $50 \mathrm{mgCo} / \mathrm{kgsoil}$ and the lowest value of $0.060 \%$, $0.041 \%$ at $200 \mathrm{mgCo} / \mathrm{kgsoil}$ respectively compared with the control (Fig. 3).

The effect of cobalt level on potassium content of shoots and roots of alfalfa plants is represented in Fig( 4 ) and showed that the highest value of $1.552 \%, 0.384 \%$ was obtained at the application of $50 \mathrm{mgCo} / \mathrm{kgsoil}$ and the lowest value of $0.0 .269 \%$, $0.092 \%$ at $200 \mathrm{mgCo} / \mathrm{kgsoil}$ compared with the control respectively. Effect of cobalt addition on nodule formation of alfalfa plants represented in Table(2). It is clear that cobalt levels $(10-50)$ $\mathrm{mgCo} / \mathrm{kgsoil}$ significantly increased the number of pink color nodules with a range of 8-24 nodule / plant compared with the control mostly centered around the top root. The highest number of root nodules was obtained at application of $50 \mathrm{mgCo} / \mathrm{kgsoil}$ and further increase in the cobalt level $(75-200) \mathrm{mgCo} / \mathrm{kgsoil}$ decreased root nodule formation .

The amount of cobalt accumulated in alfalfa plants represented in Fig (5) showed that cobalt content in shoots, roots and nodules were significantly increased by increasing cobalt level in the soil $\mathrm{R}^{2}=$ $0.9560, R^{2}=9839$ and $R^{2}=0.9564$ respectively. The root cobalt contents were higher than those obtained in the shoots.

The photosynthetic pigments such as chlorophylla,chlorophyll - b, total chlorophyll and carotinoid contents of alfalfa leaves are represented in Table(4) . Presented data reveal that the levels of ( 0 $, 10, \quad 25,35$ and 50$) \mathrm{mgCo} / \mathrm{kgsoil}$ significantly increased the photosynthetic pigments .The highest level recorded at of $50 \mathrm{mgCo} / \mathrm{kgSoil}$ and decreased with higher application of cobalt . Reduction in pigments content of the leaves varied with the increasing cobalt level . It may be due to supply of excess amount of cobalt prevent the incorporation of iron in protoporphyrin molecule because the formation of chlorophyll pigments depend on the adequate supply of iron (Vijayarengan and Dhanavel, 2005) and the interference with other heavy metals in the synthesis of pigments .Inhibition uptake and transportation of other metals such as $\mathrm{Mn}, \mathrm{Zn}$ and $\mathrm{Fe}$ by antagonistic effect (Baker1981

Table(1):Some physical and chemical properties of the studied soil

\begin{tabular}{|c|c|c|c|}
\hline Property & Value & Property & Value \\
\hline Texture & $\begin{array}{c}\text { Silty Clay Loam } \\
\text { (SCL) }\end{array}$ & Total Cobalt mgkg $^{-1}$ & 32.64 \\
\hline $\mathbf{p H}_{\mathrm{s}}$ & 7.86 & $\begin{array}{c}\text { Available Cobalt } \\
\text { mgkg }^{-1}\end{array}$ & 0.48 \\
\hline $\mathrm{EC}_{25}\left(\mathrm{dS} \cdot \mathrm{m}^{-1}\right)$ & 0.46 & $\mathrm{Ca}^{++} \mathrm{mol}_{\mathrm{c}} \mathrm{m}^{-3}$ & 32.41 \\
\hline Organic Mater $\left(\right.$ gmkg $\left.^{-1}\right)$ & 11.12 & $\mathrm{Mg}^{++} \mathrm{mol}_{\mathrm{c}} \mathrm{m}^{-3}$ & 7.49 \\
\hline $\mathrm{CEC}\left(\mathrm{Cmol}_{+} \cdot \mathrm{kg}^{-1}\right)$ & 40.1 & $\mathrm{Na}^{+} \mathrm{mol}_{\mathrm{c}} \mathrm{m}^{-3}$ & 4.54 \\
\hline Total $\mathrm{CaCO}_{3}\left(\mathrm{gmkg}^{-1}\right)$ & 387.2 & $\mathrm{~K}^{+} \mathrm{mol}_{\mathrm{c}} \mathrm{m}^{-3}$ & 1.22 \\
\hline Active $\mathrm{CO}_{3}\left(\mathrm{gmkg}^{-1}\right)$ & 170.8 & $\mathrm{SO}_{4}{ }^{=} \mathrm{mol}_{\mathrm{c}} \mathrm{m}^{-3}$ & 1.92 \\
\hline Total Nitrogen $\left(\mathrm{gmkg}^{-1}\right)$ & 24 & $\mathrm{Cl}^{-} \mathrm{mol}_{\mathrm{c}} \mathrm{m}^{-3}$ & 0.84 \\
\hline Available $\mathrm{P}\left(\mathrm{mgkg}^{-1}\right)$ & 20.12 & $\mathrm{HCO}_{3}{ }^{=} \mathrm{mol}_{\mathrm{c}} \mathrm{m}^{-3}$ & 3.37 \\
\hline
\end{tabular}




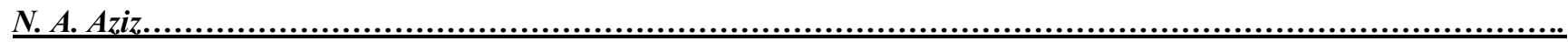

Table (2): Effect of Cobalt application on nodule formation of alfalfa

(Medicago sativa L.) plants

\begin{tabular}{|c|c|c|c|c|c|}
\hline \multirow{2}{*}{$\begin{array}{c}\text { Cobalt levels } \\
\text { (mg/kg soil) }\end{array}$} & \multicolumn{2}{|c|}{$\begin{array}{c}\text { No.of Nodules } \\
\text { /plant }\end{array}$} & \multirow{2}{*}{$\begin{array}{l}\text { Cobalt levels } \\
\text { (mg/kg soil) }\end{array}$} & \multicolumn{2}{|c|}{ No.of Nodules/plant } \\
\hline & Pink & Gray & & Pink & Gray \\
\hline Control & $4^{a}$ & $3^{a}$ & 75 & 11 & $5^{b}$ \\
\hline 10 & 8 & $6^{b}$ & 100 & $4^{a}$ & $6^{b}$ \\
\hline 25 & 12 & $3^{a}$ & 150 & $4^{a}$ & $6^{b}$ \\
\hline 35 & 14 & $3^{\mathrm{a}}$ & 200 & $4^{a}$ & $6^{b}$ \\
\hline 50 & 24 & $6^{b}$ & & & \\
\hline
\end{tabular}

Number of nodules is given as a mean of four replications

Values which sharing a common superscript not differ significantly at $P<0.05(D M R T)$

Table (3) Effect of concentration of added cobalt on protein content of alfalfa (Medicago sativa L.)plant shoots.

\begin{tabular}{|c|c|c|c|}
\hline $\begin{array}{c}\text { Cobalt } \\
\text { levels } \\
\text { (mg/kg soil) }\end{array}$ & $\begin{array}{c}\text { protein } \\
\text { in shoots } \\
\%\end{array}$ & $\begin{array}{c}\text { Cobalt } \\
\text { levels } \\
\text { (mg/kg soil) }\end{array}$ & $\begin{array}{c}\text { Protein } \\
\%\end{array}$ \\
\hline $\mathbf{0}$ & $\mathbf{5 . 0 2 5}^{\mathrm{a}}$ & $\mathbf{7 5}$ & $\mathbf{1 2 . 9 1 9}$ \\
\hline 10 & $\mathbf{6 . 4 1 3}$ & 100 & $\mathbf{6 . 9 8 1}$ \\
\hline 25 & $\mathbf{8 . 9 4 4}$ & 150 & $\mathbf{4 . 6 7 5}^{\mathrm{a}}$ \\
\hline 35 & $\mathbf{1 4 . 0 6 2 5}$ & $\mathbf{2 0 0}$ & $\mathbf{4 . 0 2 5}^{\mathrm{a}}$ \\
\hline 50 & $\mathbf{2 0 . 3 8 8}$ & & \\
\hline
\end{tabular}

Number of nodules is given as a mean of four replications Values which sharing a common superscript do not differ significantly at $\mathbf{P}<$ 0.05(DMRT) nitrogen, phosphorous and potassium concentration in both shoot and roots, shoot protein content, photosynthetic pigments content and nodules. The highest value of all studied parameters were found at cobalt treatment of $50 \mathrm{mgCo} . / \mathrm{kg}$ soil with a significant difference .In the present studied calcareous soil,a gradual decline was observed with increasing the cobalt levels. However, the cobalt content in shoot, root and nodules of alfalfa plants were significantly increased by increasing cobalt level in soil with a correlation coefficients of $R^{2}=0.956, R^{2}=9839$ and $\mathrm{R}^{2}=0.9564$, respectively, and the root

Table (4): Effect of Cobalt application on pigment contents of alfalfa (Medicago sativa L.) plants.

\begin{tabular}{|c|c|c|c|c|}
\hline $\begin{array}{l}\text { Added Cobalt } \\
\text { (mg/kg soil) }\end{array}$ & $\begin{array}{c}\text { Total chlorophyll } \\
\text { mg/gm }\end{array}$ & $\begin{array}{c}\text { Chlorophyll a } \\
\text { mg/gm }\end{array}$ & $\begin{array}{c}\text { Chlorophyll b } \\
\text { mg/gm }\end{array}$ & $\begin{array}{c}\text { Carotinoid } \\
\text { mg/gm }\end{array}$ \\
\hline $\mathbf{0}$ & 1.224 & 0.488 & 0.736 & $0.0546^{\mathrm{a}}$ \\
\hline 10 & $1.448^{\mathrm{a}}$ & 0.599 & 0.860 & 0.0884 \\
\hline 25 & 1.742 & $0.622^{\mathrm{a}}$ & 1.120 & 0.1122 \\
\hline 35 & 1.865 & $0.642^{\mathrm{a}}$ & 1.223 & 0.1246 \\
\hline 50 & 2.0565 & 0.687 & 1.369 & 0.1434 \\
\hline 75 & $1.389^{\mathrm{a}}$ & 0.401 & 0.988 & 0.0746 \\
\hline 100 & 0.842 & 0.352 & 0.490 & $0.0548^{\mathrm{a}}$ \\
\hline 150 & 0.633 & 0.264 & 0.369 & 0.0371 \\
\hline 200 & 0.381 & 0.128 & 0.153 & 0.0221 \\
\hline
\end{tabular}

Number of nodule is given as a mean of four replications

Values which sharing a common superscript do not differ significantly at $\mathrm{P}<0.05$ (DMRT)

and Cobbett 2000).

In conclusions, applications of different levels of (10-50) $\mathrm{mgCo} / \mathrm{kg}$ soil led to an increase in biomass content, yield responses to cobalt were always accompanied by increasing cobalt contents were higher than those obtained in shoots. From the present investigation it can be concluded that application of $50 \mathrm{mg} \mathrm{Co} / \mathrm{kg}$ soil cobalt in soil is beneficial for alfalfa plant growth in a soil with high lime content. 

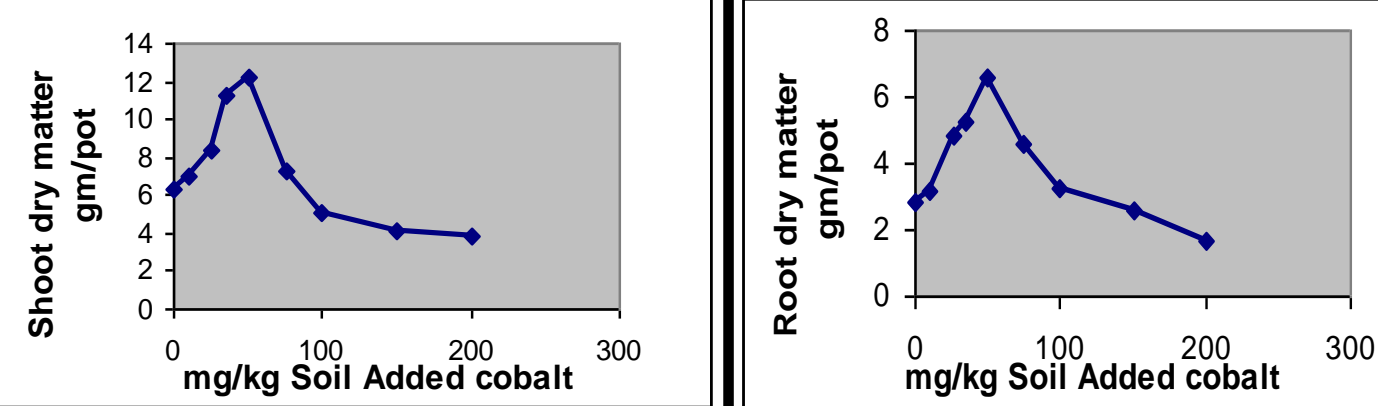

Fig. (1):Effect of concentration of added cobalt on dry matter weight of Alfalfa (Medicago sativa $\mathbf{L}$.) plants.
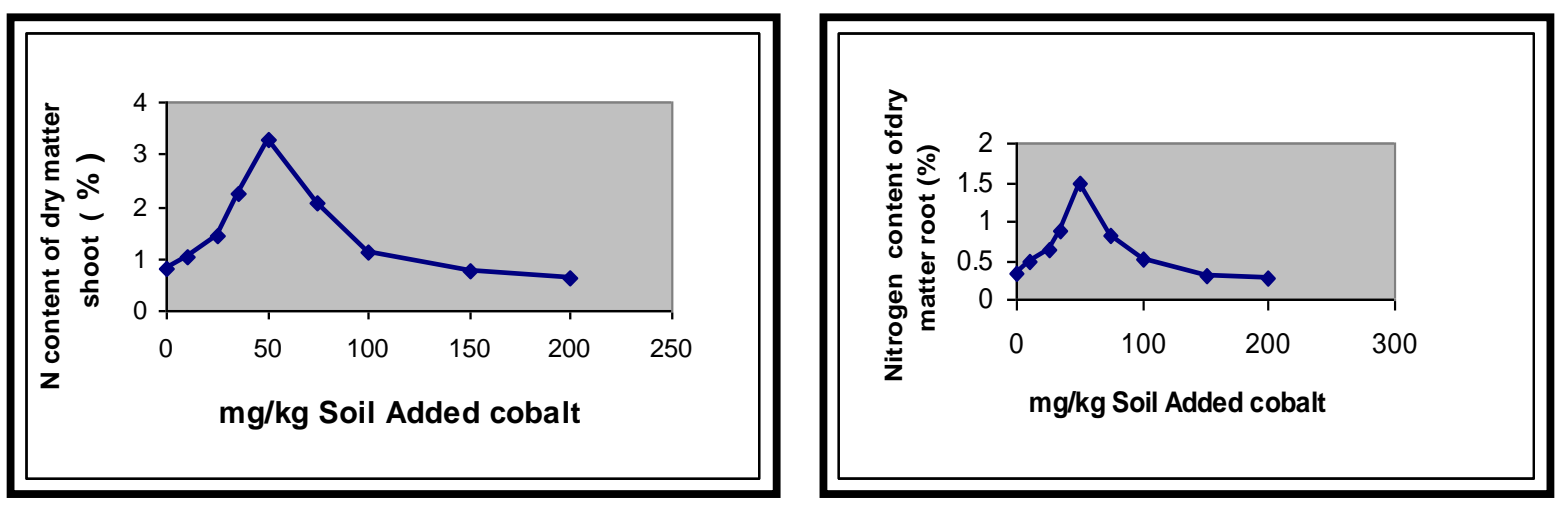

Fig. (2):Effect of concentration of added cobalt on Nitrogen content of Alfalfa ( Medicago sativa L. ) plants.
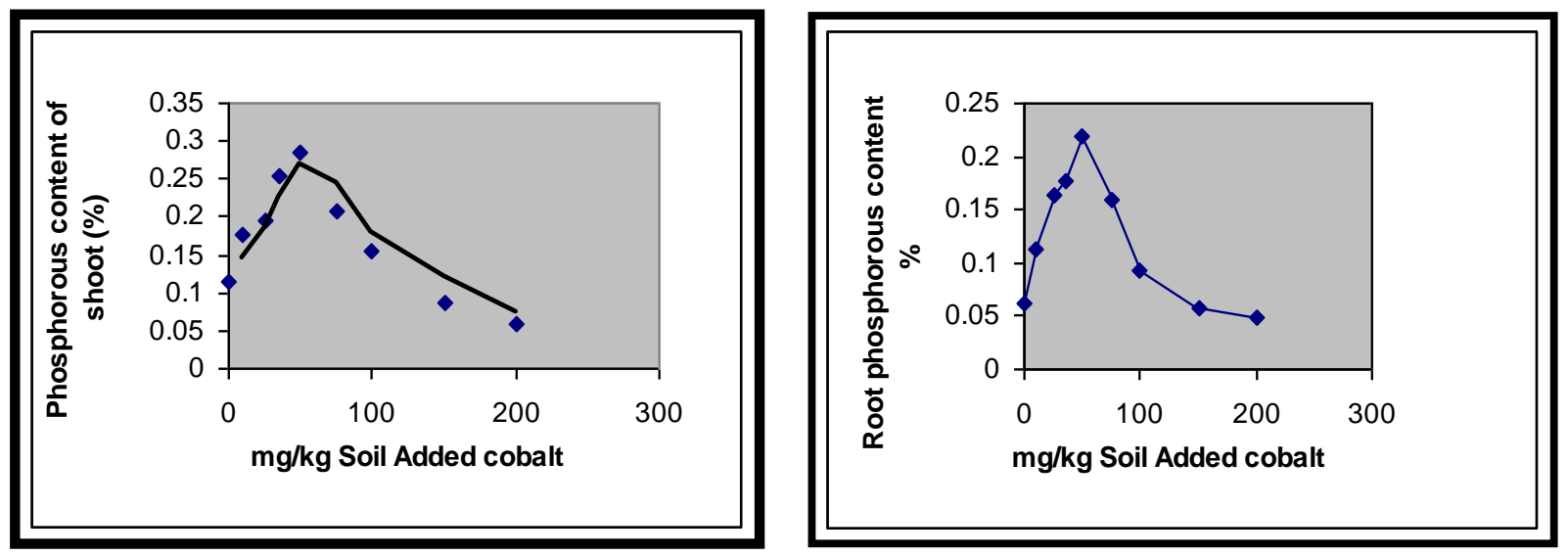

Fig. (3): Effect of concentration of added cobalt on Phosphorous content of Alfalfa ( Medicago sativa $\mathbf{L}$. ) plants. 

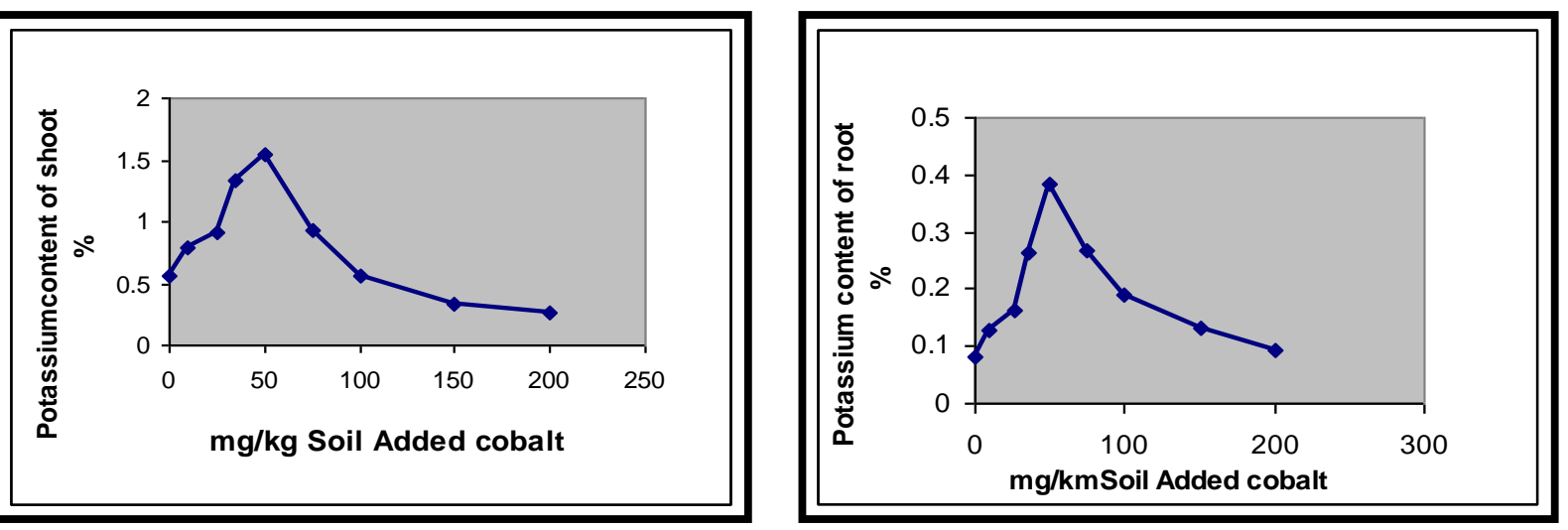

Fig. (4): Effect of concentration of added cobalt on Potassium content of Alfalfa ( Medicago sativa L. ) plants.
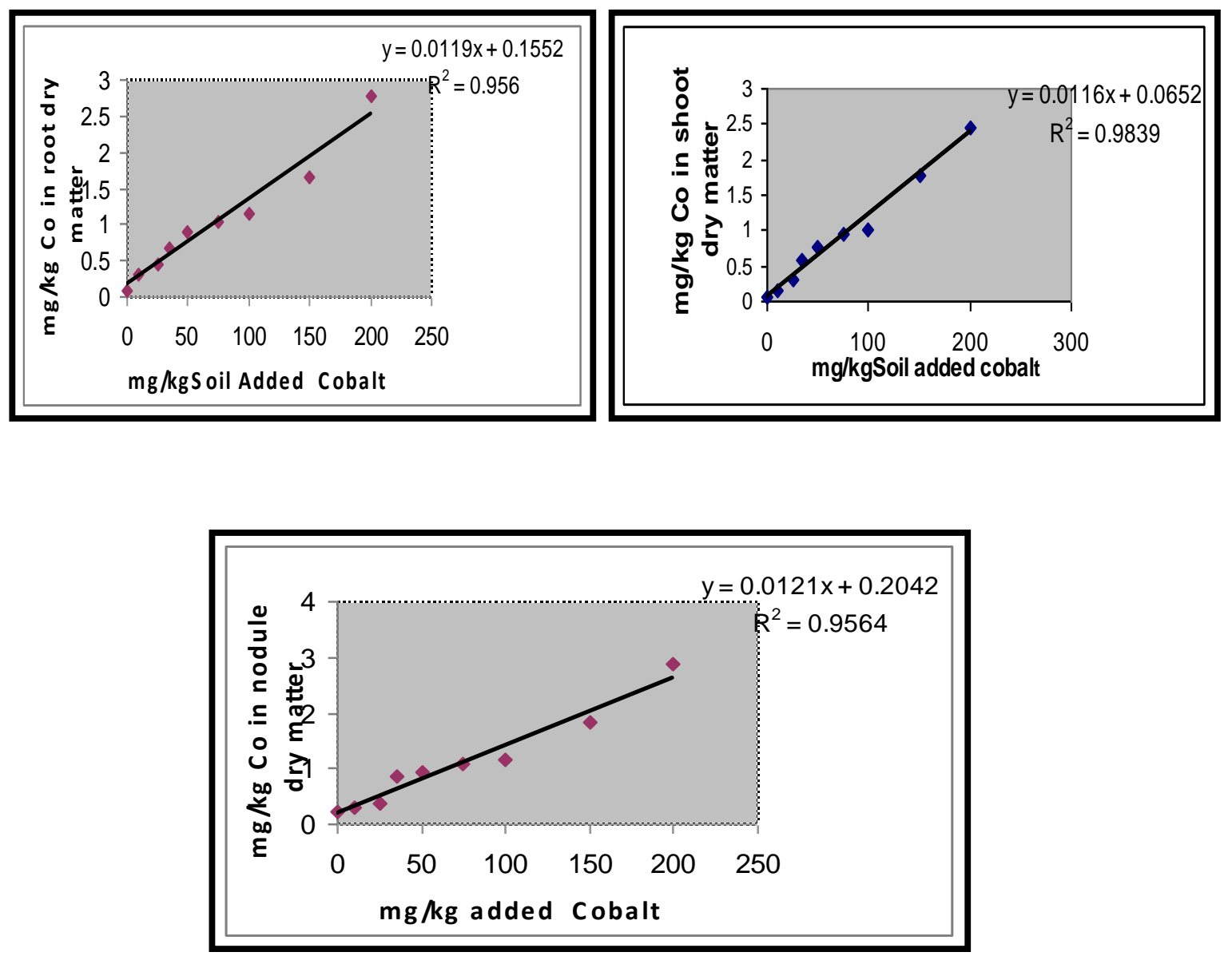

Fig. (5): Effect of added cobalt concentration on accumulation of cobalt in alfalfa (Medicago sativa $\mathbf{L}$.) plants. 


\section{REFERENCES}

Abd El-Moez and Gad N. (2002). Effect of organic cotton compost and cobalt application on cowpea plants growth and mineral composition. Egypt J. Appl . Sci ., 17 : 426 440.

Baker A.J.M.(1981).Accumulators and excluders strategies in the response of plants heavy metals J. Plant Nutr ., 3:643-654.

Basu M ., Bhadoria P. B. S. and Mahapatra S.C. (2006).Influence of micro-nutrient improving the groundnut productivity under alluvial soil of India. Acta . Agricultural Slovenica, 87: 435-444

Black C.A . (1965) . Methods of Soil Analyses . Agron .Mono. 9 .part 1 ,2 Am. Soc Agron. Madison Winsconsis.

Brady N. C. and Ray R . W.(2000) .The Elements of the Nature and Properties of Soils. Upper SaddleRover, New Jersey : Prentice .

Bruce T. R. and Riggs W.(2002 ).Alfalfa for Beef Cows . University of Nivad, a Cattle Producer s Library $2^{\text {nd }}$ ed . 319.

Bruins M.R., Kaoil S. and Oehme F .W. (2000) . Microbial resistance to metalsin the environment Ecotoxicol and Environ Safety ,45 : $198-207$.

Cobbett C.S. (2000). Phytochelatins and their roles in heavy metal detoxification. Plant Physiology ., $123: 825-832$.

Dilworth M . J ., Robson AD and Chatel D.L . (1979). Cobalt and nitrogen fixation in nodule formation and functions. New phytol 83: 63 73

El- Sheekh M.M ., El-Naggar A.H and El Mazaly M.E.H.E.(2003) .Effect of cobalt on growth, pigment and the photosynthetic electron transport in Monoraphidium minutum and Nitzhia perminuta .Brazilian Jornal of Plant Physiology 15:159- 166.

Fodor F .,Cseh E .,Varga A . and Zaray Gy (1998). Lead uptake distribution, and remobilizationn cucumber. J. plant Nutr.21 : 1963 - 1373.

Hala Kandil (2007) .Effect of Cobalt Fertilizer on growth, yield and nutrients status of Faba Bean (Vicia faba L.) Plants . J. Applied Sciences Research,3 (9) : 867-872.

Havlin J.L., Beaton J.D ., Tisdal S.L . and Nelson W.L .(2005). Soil Fertility and Fertilizers . $7^{\text {th }}$ Ed . An Introduction to Nutrient Management. Prentice-Hall , Inc ., N . J .290-291.

Hesse P.R. (1971). A text book of soil chemical analysis . Chemical Publishing Co.Inc., New York. 81-83.
Jackson, M.L (1973) . Soil chemical analysis . Prentice - Hall . Inc. Englewood . Cliffs , N.J . 46-47

Jayakumar K. and Vijayarengan P. (2006). Alterations in the carbohydrate metabolism of Vigna mungo L. Hepper as affected by cobalt stress . Indian Journal of Enviromental and Ecoplanning 3:1821

Karim , T.H . (2000).Models to predict water retention of Iraq soils. Indian Journal of soil Sci. 47: 19 -23.

Khalil A.A., Mohamed S. S .,Taha F.S and Karlsson E.N.(2006).Production of functional protein hydrolysates from Egyptian breeds of soybean and lupine seeds .African J.Biotechnol ., 5 ( 10 ) : 907-916.

Kozhekov D. K and Yakovleva (1977). .Determination of carbonates and carbonate minerals in soils. Soviet Sci . J . 10 : 620-626.

Laila M.H. and Gad Sh . Nadia (2002). Soviet Sci . J . $10: 620-626$. Effect of cobalt fertilization on yield quality and essential oil composition of parsley leaves . J . Agric . Sci . Ain Shams Univ.Cairo10:803-829.

Lindsay W. L. and Norvell W.A. (1978). Development of DTPA micronutrient soil test for $\mathrm{Zn}, \mathrm{Fe}, \mathrm{Mn}$, and Co..Soil . Soc . Amer . 42: 421-428.

Marschner H. (2003).Mineral Nutrition of Higher Plant . Acadmic press New York P: 210-228

Mihler R.L. and Tindall T.A. (2002). Alfalfa Northern Idaho Fertilizer Guide, Idaho Univ. of Idaho, College of Agricultural and Life Science.

O. Hara ,G.W.(2001). Nutritional constrain on root nodule bacteria affecting symbiotic. A review - Australian Journal of nitrogen fixation Experimental Agriculture 41:417-433.

Page A . L.(1982) . Methods of Soil Analysis. Part 2 Amer . Soc . Agriconomy . Pub .Madison ,Wisconsin .U.S.A P539.

Pilon-Smits Quinn EAH,Tapkew CF,Malagoli W. and Aschiavon M . (2009) . Physiological functions of beneficial elements ,Curropin plant bio.12:267-274.

Rowell,D.L.(1996). Soil Science .Method of application .University of Reading. U.K.

Ryan J., Estefan G. and Rashid A. (2001). Soil and plant analysis laboratory manual. 2Ed.ISBN.No.92:9 P127-118

Saeed ,K.S .(1989) .Effect of Rhizobium, N and Mo on productivity and quality of annual medic . M.Sc. Thesis Agr . college, Baghdad Univ. Iraq . 
Scott G.and William K.P.(1976).Cobalt and plant development. Plant and plant development . Plant physiology.57. 886 889.

Vijayarengan P.(2004). Growth, nodulation and dry matter yield of black-gram cultivars under nickel stress. Journal of
Environmental Science and Engineering 46:151-158 .

Vijayarengan P. and Dhanavel D. (2005) . Effect of nickel on chlorophyll content of blackgram cultivars . Advance in plant Science .18: 253-257.

تأثير إضافة مستويات مختلفة من الكوبالت على المحصول وتكوين العقد الجذرية، ومحتوى النيتروجين والفسفور

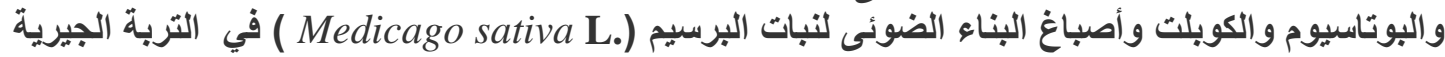

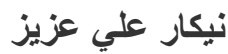

$$
\begin{aligned}
& \text { قسم البستنة ـ كلية الزر اعة -جامعة كركوك ــ العر اق }
\end{aligned}
$$

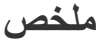

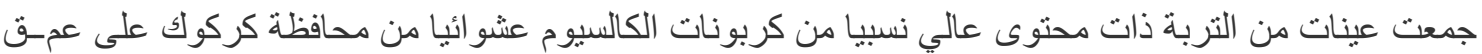

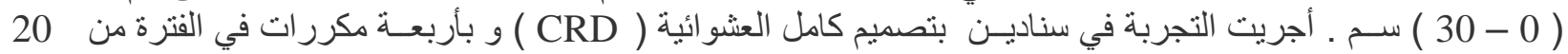

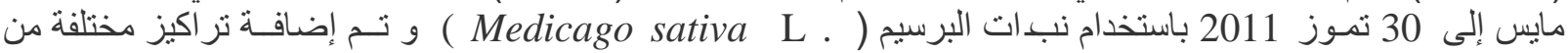

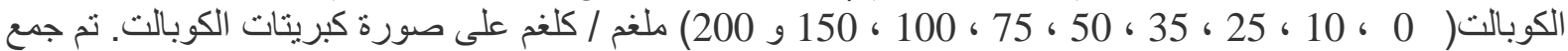

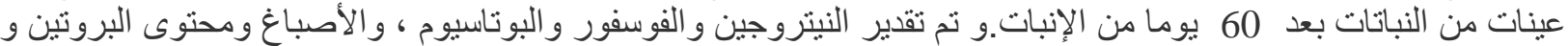

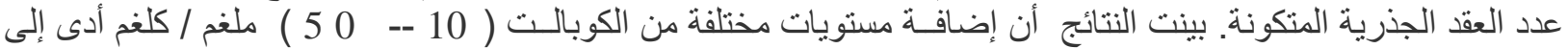

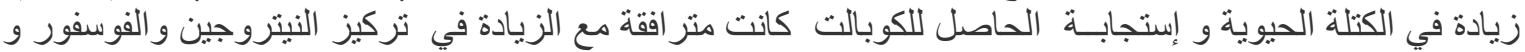

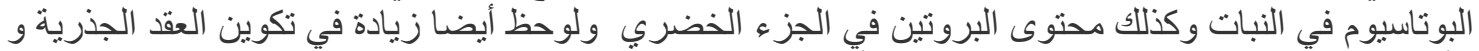

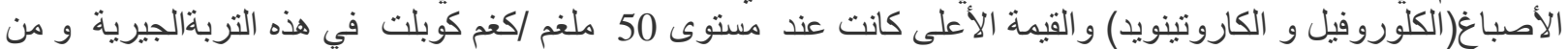

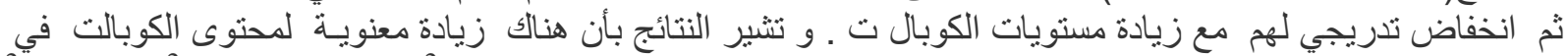

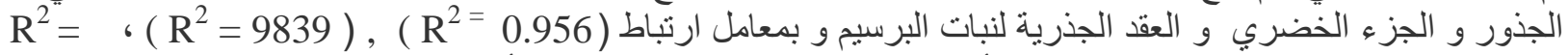

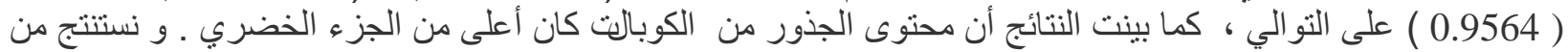

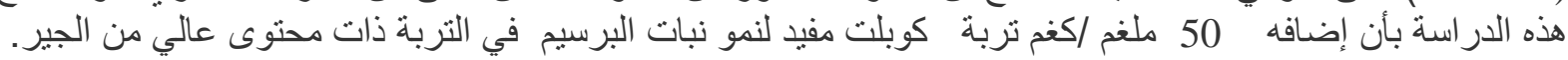

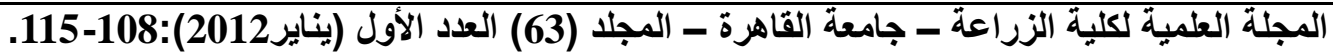

